\title{
INTEGRATED STUDIES FOR MAPPING OF URANIUM MINERALIZATION IN "NUGURS-SIKAIT-ABU RUSHEID" AREA SOUTH EASTERN DESERT, EGYPT
}

\author{
Mousa, M. I., Mansour, G. M., Abd El Azeem, A. H., and Saleh, Kh. E. \\ Nuclear Materials Authority, P.O. Box 530, El Maadi, Cairo, Egypt
}

\begin{abstract}
The investigated area is a part of Wadi (W.) Al Gemal basin and located about $45 \mathrm{~km}$ southwest of Marsa Alam town, South Eastern Desert of Egypt. It is dissected by numerous radioactive structurally controlled mineralizations along W. Nugrus, W. Sikait and W. Abu Rusheid environs. Recently, the Nuclear Materials Authority of Egypt (NMA) launched an exploration prospect for these nuclear materials. This study deals with multidisciplinary research by technological advances for data acquisition and analysis of radio-elements exploration approach. Integration for all available data of the studied area, used multiple system for analyses, such technique gives us maps represented by location, quantity, form, type and growing up of anomalies. In order to solve the accuracy problems of a radio-elements, exploration consisting of both geophysical and geochemical analyses with Landsat 7 (ETM+) images, a multidisciplinary model can be carried out using GIS software (i.e. Erdas imagine, Arc GIS, Oasis Montage and Envi packages). The structural lineament analyses and the discriminated lithologic units of "Nugurs-Sikait-Abu Rusheid" area are integrated to show their relationships to the high radioactivity occurrences. N-S and NW-SE trends are the predominant regional structural lineament trends while NESW and ENE-WSW are minors in the investigated area. The highest radioactivity zones of the study area are restricted to cataclastics domain, followed by younger granitic rocks in the Nugrus-Sikait area. Chemical studies reveal to rubidium and uranium show their higher content at the cataclastic rocks of the Abu Rusheid area. At least, model output gives us area of interest for high radioelements locate within the cataclasic rocks; where the areas of interest for uranium, thorium and potassium anomalies have 2.84, 1.99 and $2.88 \mathrm{~km}^{2}$, respectively. Also, an area of interest for higher geochemical analysis gives us an idea about the zinc highest content which has $0.284 \mathrm{~km}^{2}$ in cataclasitc rocks in the Abu Rusheid area.
\end{abstract}

Keywords: Remote sensing, geophysical data, geochemical data, database model, radio-elements, Nugrus, Sikait, Abu Rusheid.

\section{INTRODUCTION}

The investigated area is a part of Wadi (W.) Al Gemal basin located about $45 \mathrm{~km}$ southwest of Marsa Alam coastal town, South Eastern Desert of Egypt. The area is bounded by latitudes $24^{\circ} 35^{\prime} 10^{\prime \prime}$ $24^{\circ} 41^{\prime} 10^{\prime \prime} \mathrm{N}$ and longitudes $34^{\circ} 43^{`} 50^{\prime \prime}-34^{\circ} 50^{\prime} 00^{\prime}$ 'E (Fig. 1) and covers $\sim 125 \mathrm{~km}^{2}$. The investigated area is fish-shaped body, characterized by moderate elevation; Gabal (G.) Sikait is the highest topographic feature (769 m above sea level). The area is dissected by numerous structurally controlled NW and N-S wadies (i.e. Nugrus, Sikait, and Abu Rusheid) and ravines in a dendritic pattern.

Regionally, the investigated area lays out a region occupied by ophiolitic thrust sheets pierced by gneiss domes forming structural highs, such as a Nugrus-Sikait dome. Accordingly, the area comprises two thrust napes (ophiolite rocks and arc assemblages) separated by ophiolitic mélange rocks. It can be summarized as follows (younger to older); i) upper nape rocks includes meta-peridiotites, metagabbros and ophiolitic mélange and ii) lower nappe rocks composed of metasediments, cataclastics and intrusive rocks (gabbros, biotite and muscovite monzogranites, alkali feldspar granite. The Nugrus-Sikait dome is composed of variably deformed gneisses, schists, amphibolites and granites, all representing an attenuated ancient continental crust and surrounded by a carapace of mylonites developed along the sole thrust at the base of the overthrusted ophiolitic mélange napes (Mansour, 2005 and Ibrahim, 2009). The cataclastic rocks of eastern shoulder of W. Abu Rusheid cover $>3 \mathrm{~km}^{2}$ and classified according to (Higgins, 1975 
and Ibrahim et al., 2004) into protomylonites, mylonites, ultramylonites and silicified ultramylonites with gradational contacts. These rocks are cut by several shear zones which mostly emplaced by lamprophyre dykes bearing $\mathrm{Zn}, \mathrm{Cu}$, REEs, $\mathrm{Sn}$ and radioactive mineralization. Abu Rusheid cataclastics are highly affected by faulting with main intensity of nearly N-S direction. Also, the lineaments of micro scales leave their imprint as micro-faults and foliations where mostly reflect the subsurface structures that serve as pathways for mineralized hydrothermal solutions. Comparing the lineament patterns with mineral occurrences showed that mining districts tend to occur along lineaments and are particularly concentrated at lineament intersections (Sabins, 1999).

Fig. 1: False colour Landsat image and location maps of the study area.

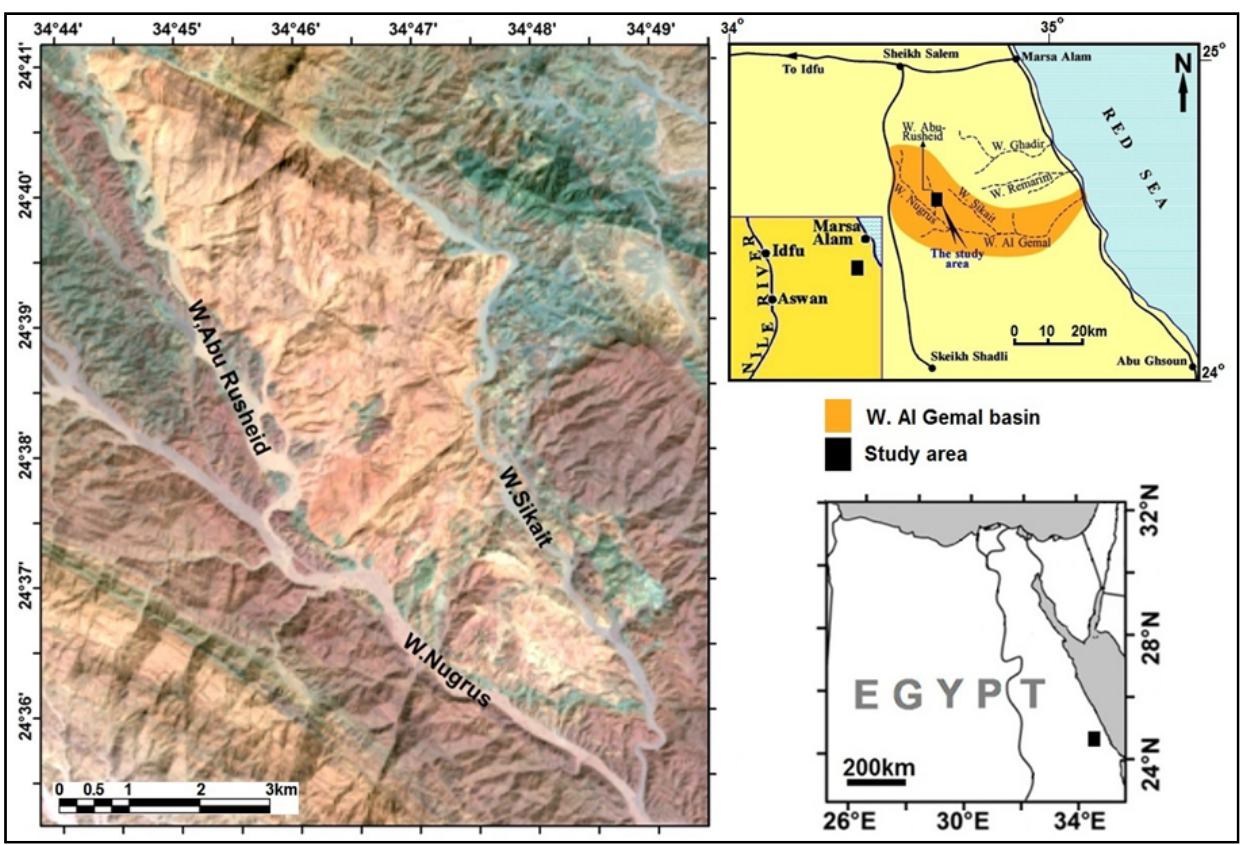

Several detailed geological, structural, geochemical and geophysical works have been carried out in the study area (e.g., Krs et al., 1973, Eid, 1986, Saleh, 1997, Ibrahim et al., 2000, Khaleal, 2005, Rashed, 2005, Mansour, 2005, Assran and Mansour, 2005 and Ibrahim, 2009). Also, many authors studied the mineralogy; i.e. Hassan, 1972, Bugrov, 1973, Abdalla, et al., 1998, Omar, 2001, Oraby, et al., 2003, Khaleal, 2005, Rashed, 2005, Mansour, 2005, Ibrahim et al., 2007, Khaleal, et al., 2007, Raslan, 2008, Mahmoud, 2009, Ali et al., 2011, Ibrahim, 2011, Ali, 2012, Abu Elatta, et al., 2013 and others. Wadi Al Gemal basin occupies three important nuclear mineral resources, i.e.; i) the ancient mine dumps, which contains large reserves of beryllium (Hassan and El Shatoury, 1976; Omar, 2001 and Oraby et al., 2003), ii) the rare earth metals (REEs) (Hassan, 1964 and Osman, 2007) and iii) radioactive minerals (Hassan, 1973, Ibrahim et al., 2002, 2004 and 2006 and Mansour, 2005). Recently, the Nuclear Materials Authority of Egypt (NMA) launched a comprehensive exploration program for these variable nuclear materials named (Abu Rusheid Prospect) since 2001.

The main objectives of the present work are the integration and interpretation approach of geospatial studies, regional geological setting, geochemical and radio-elements to identify the alteration zones in study area using Landsat 7 Enhanced Thematic Mapper (ETM+) data and previous works. Also, the combination of remote sensing (RS), with pre-exists geochemical and geophysical datasets were carried out to confirm anomalous mineralization zones.

\section{MATERIALS AND METHODS}

\section{Data Used for the Study Area}

The methodology involved satellite remote sensing based on spectral studies supplemented by previous field geological investigations as well as geochemical sampling analysis and geophysical studies. Each 
Integrated studies for mapping of uranium mineralization

technique supplemented the other, leading to increased confidence in interpretations at every stage. Each stage of study helped prioritization of target for subsequent stages of investigation.

Landsat 7 Enhanced Thematic Mapper plus (ETM+) data which covering the study area were processed for geological and structural mapping with the particular aim of discriminating uraniferous granites and associated alteration zones, Landsat image of scene number (path $/ \mathrm{raw}=173 / 43$ ) consisted of 9 bands and acquisition date of this data is ( $5^{\text {th }}$ Oct. 2000). Geological maps of the previous works and topographic sheets of scale 1:50,000 constructed by the Egyptian General Survey Authority (1989) are used in this study. Several products including false-color composite image [7, 4, 2 in Red (R), Green (G), Blue (B)], band ratio image (5/7, 5/4, 3/1 in R, G and B), as well as principal component and edge enhancement for lineament extraction were obtained.

A radiometric survey of the study area has been carried using the portable GS-512 spectrometer to get contour maps, illustrating the distribution of radioactivity ( $\mathrm{K} \%$, eTh and eU in ppm). Gamma-ray spectrometry is a method for estimating the three-radioelement $(\mathrm{K}, \mathrm{U}$ and $\mathrm{Th})$ concentrations near the surface of the earth. Interpretation of radiometric survey gives us identification about the high ore concentration zones and their trend in the probable areas. Radiometric data were collected and converted to radiometric anomaly map.

Geochemical analysis of some elements (in ppm) such as potassium, uranium, thorium, as well as rubidium, strontium, zinc, zirconium and other associated elements were carried out to improve the subsequent processing, exploration quality and optimized for output results, a series of processing were applied in flow chart for data modeling of radioelement's exploration as in figure (2).

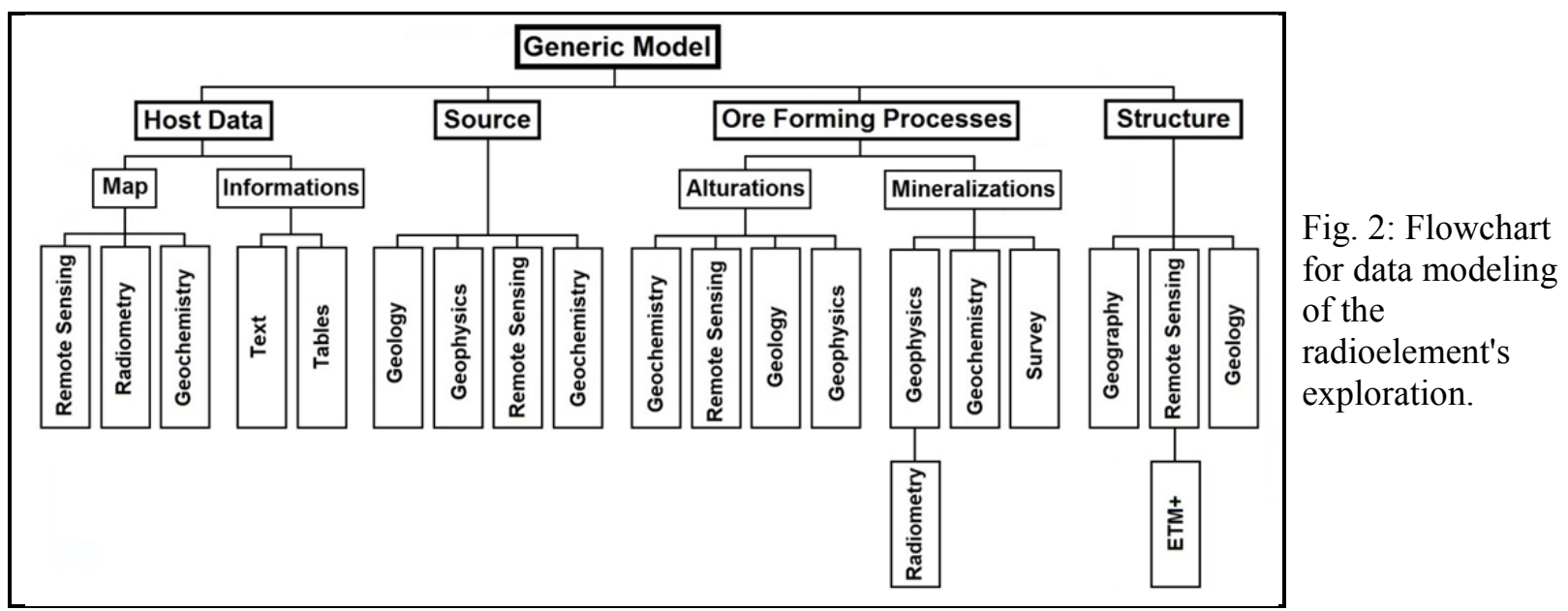

\section{Construction of an optimum FCC image}

Satellite Landsat $7(\mathrm{ETM}+)$ data bands 7, 4 and 2 were used to construct a false color composite image of scale 1:100,000 for the study area in red (R), green $(\mathrm{G})$ and blue (B) respectively (Fig. 3). Histogram equalization enhancement was carried out for the prepared FCC Landsat image to be more interpretable. Visual inspection of the FCC image shows that the metagabbros corresponds to brownish green to green color, the granites corresponds to reddish brown color, ophiolitic mélange corresponds to dark green . The granitoids in the central part of the mapped area have been delineated and identified by their lighter pink color and brown respectively, while the dark color distinguish the metasediments and mafic-ultramafic rocks.

\section{Band ratio of Landsat ETM+ data}

The band ratio technique is applied by dividing the DN pixel values of one band by the DN pixel values of another band (Drury, 1993). The geological mapping of the study area using band ratios of Landsat 7 thematic mapper, were carried out by Sultan et al. (1987). The most common type of alteration is the breakdown of feldspars and ferromagnesian minerals to a variety of clays and other hydroxyl bearing minerals. Such minerals can be detected by remote sensing techniques since the short wave 
Mousa, M. I.

infrared (SWIR) range of their spectra exhibit absorption (Drury 1993). Landsat 7 (ETM ${ }^{+}$) images band $3 / 1$ and $5 / 7$ were selected for iron oxides and hydroxyl bearing mineral respectively (Figs. 4 and 5) whereas, band ratio $5 / 4$ has been computed to enhance possible ferrous oxides (Fig. 6). The ratio of band $5 / 7$ was used as a measure of the intensity of the hydroxyl absorption in the 2.2 to $2.4 \mu \mathrm{m}$ regions. This ratio was used because band 5 is not within the confines of the Fe-bearing alumina-silicate related or hydroxyl-related absorption features, whereas band 7 is within the hydroxyl absorption wavelengths (Sultan et al., 1987). The 5/7 band ratio image (Fig. 5) shows light tone characterizing the younger granitic rocks, due to the low content of hydroxyl-bearing minerals and opaque's. Clay alteration index map draped over 5/7 Landsat $7\left(\mathrm{ETM}^{+}\right)$ratio image of the study area.

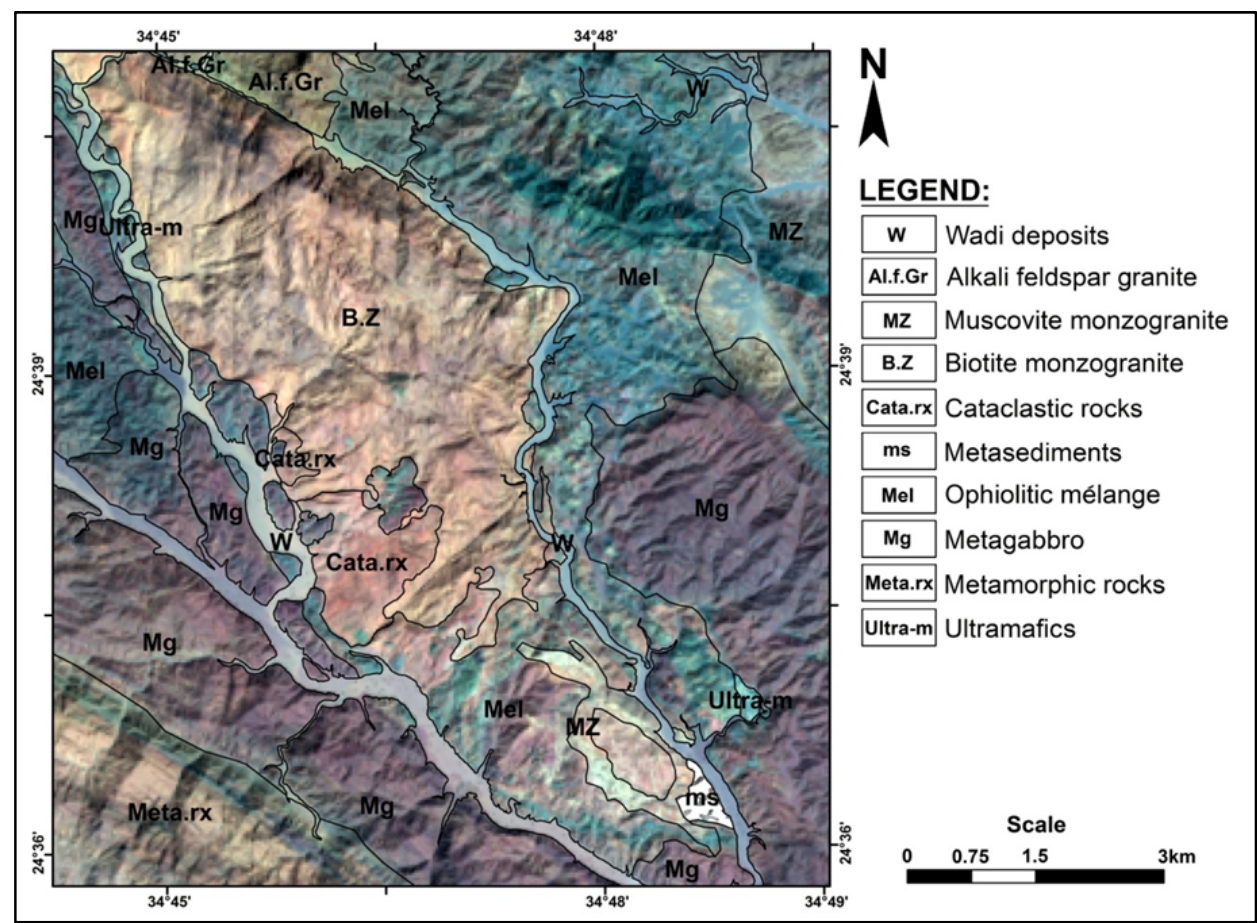

Fig. 3: False composite Landsat 7 (ETM+) image (bands, 7, 4 and 2) of Nugrus-SikaitAbu Rusheid area, South Eastern Desert, Egypt.

Fig. 4: $3 / 1$ band ratio image of iron oxides bearing mineral.

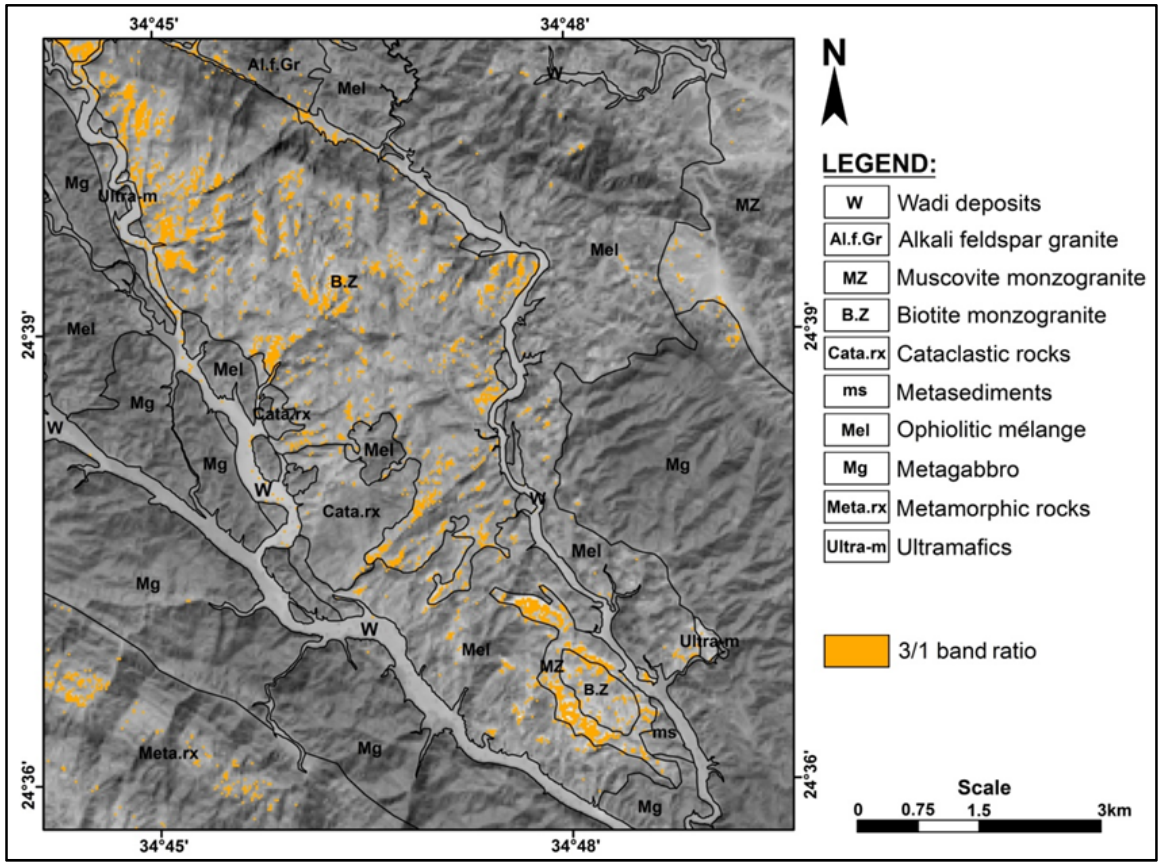


Integrated studies for mapping of uranium mineralization

Fig. 5: 5/7 band ratio image of hydroxyl bearing mineral.

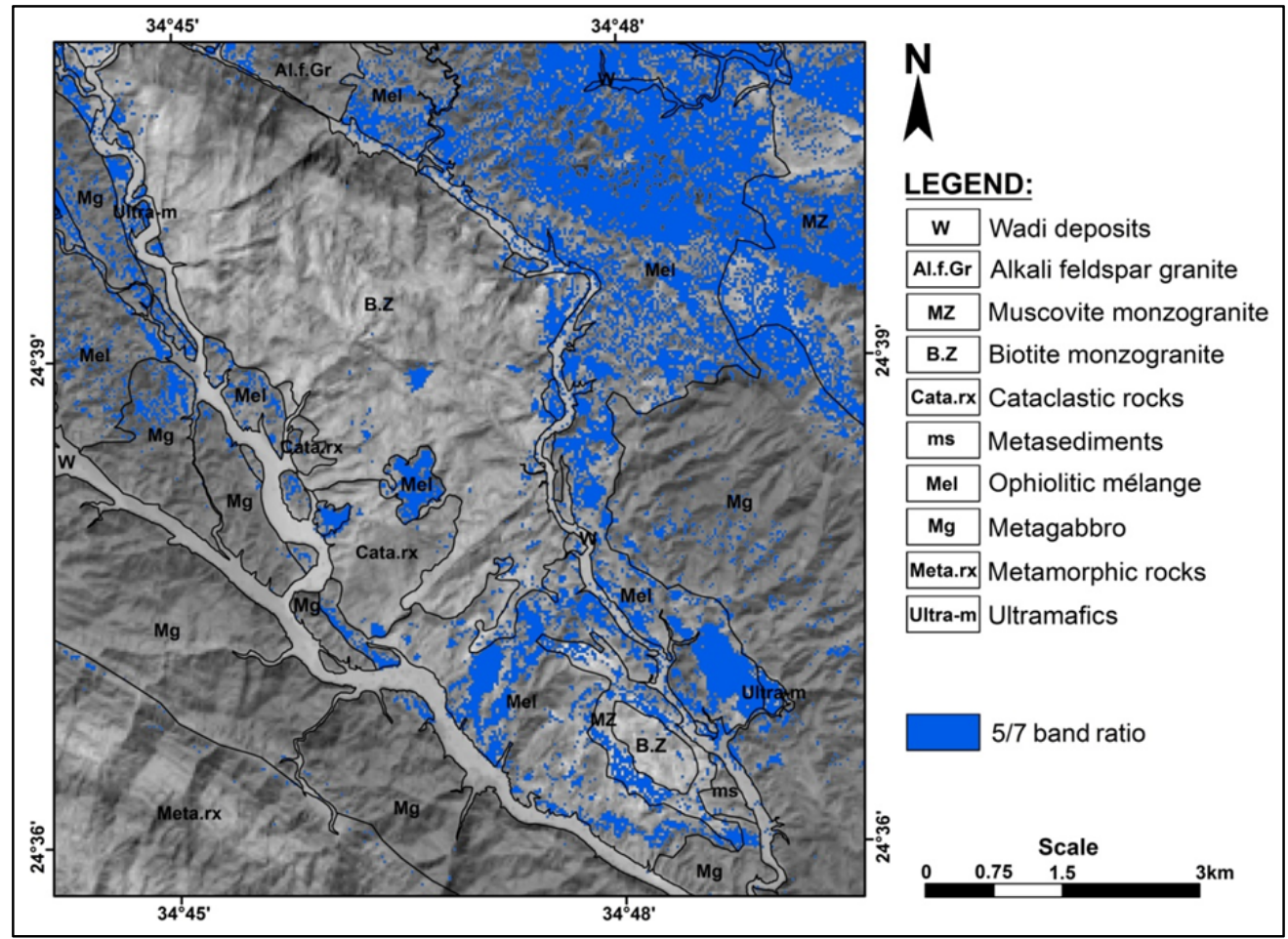

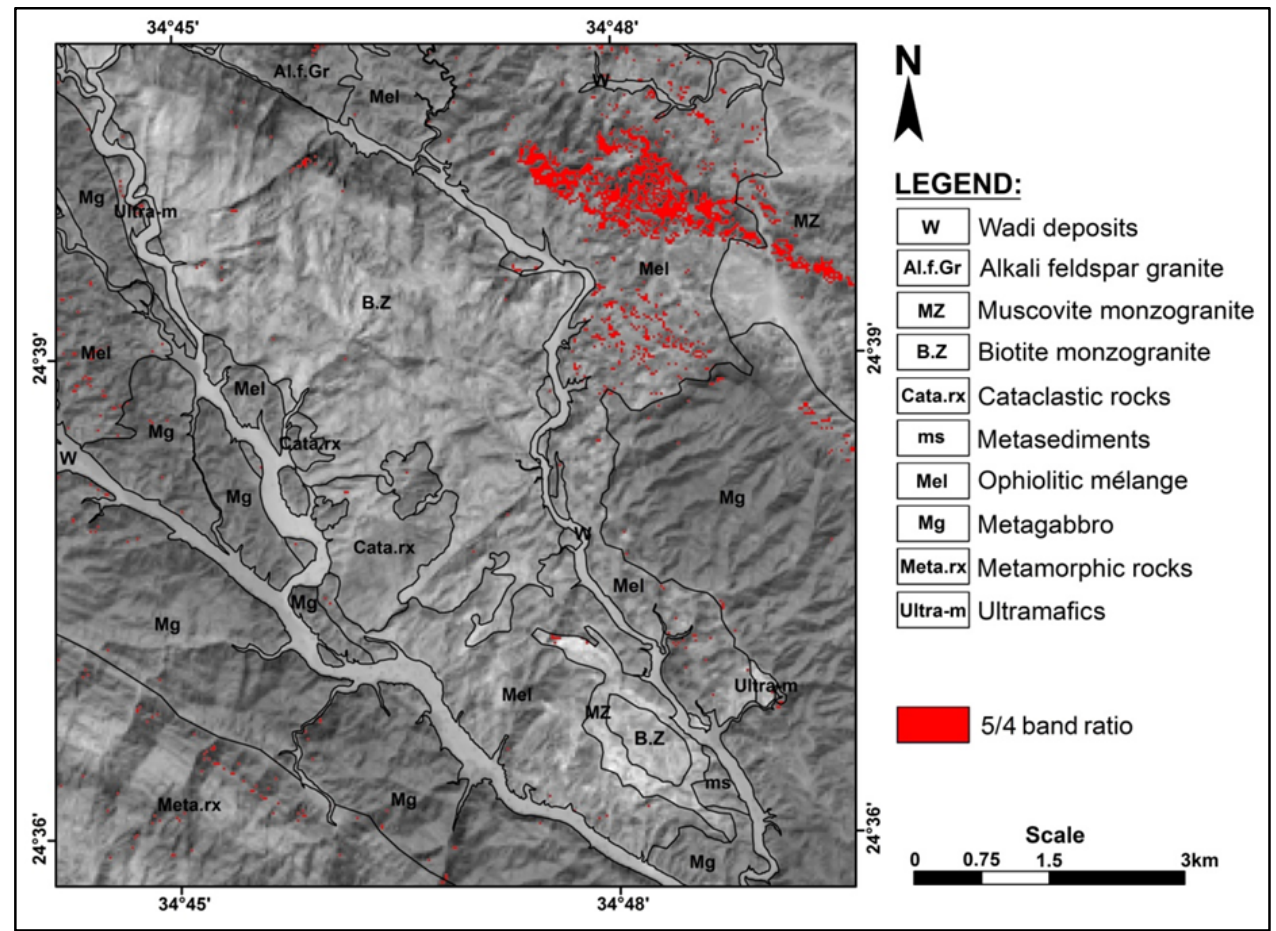

Fig. 6: 5/4 band ratio image of ferrous oxides bearing mineral.

The combinations of band ratio images $5 / 7,5 / 4$ and $3 / 1$ in $\mathrm{R}, \mathrm{G}$ and $\mathrm{B}$, respectively (Fig. 7) represent hydrothermally altered rocks and features of ferric and hydroxyl-bearing mineral. The obtained image has mapped the alteration zone ranges from yellow to pinkish. This alteration can easily be observed in the upper right corner and central part of the image. Pink color represents a mixture between hydroxyl and ferrous oxide bearing minerals in ophiolitic mélange and metagabbros, but pale blue color represents a mixture from hydroxyl bearing mineral and ferrous-bearing mineral which present at ophiolitic mélange, orange to yellow present in cataclastics and granitic rocks. 
Mousa, M. I.

\section{Principal component analysis of Landsat ETM+ data}

This technique introduces PCA as a tool in imageenhancement and analysis. PCA technique accumulates the characteristic signature of these features into a single component which enable the interpretation of features as anomalous to the surrounding that renders easy interpretation. PCA based analysis has been incorporated in the present study to distinguish the presence of uranium bearing zones. Principal Component Analysis PCA 1, PCA 2 and PCA 3 in RGB were selected to represent the best image for to distinguish desired location for highly radioactive elements. Light bearing mixture of red, green and blue represented at cataclastic rocks in the Abu Rusheid area has high radioactive anomalies, as in figure (8).

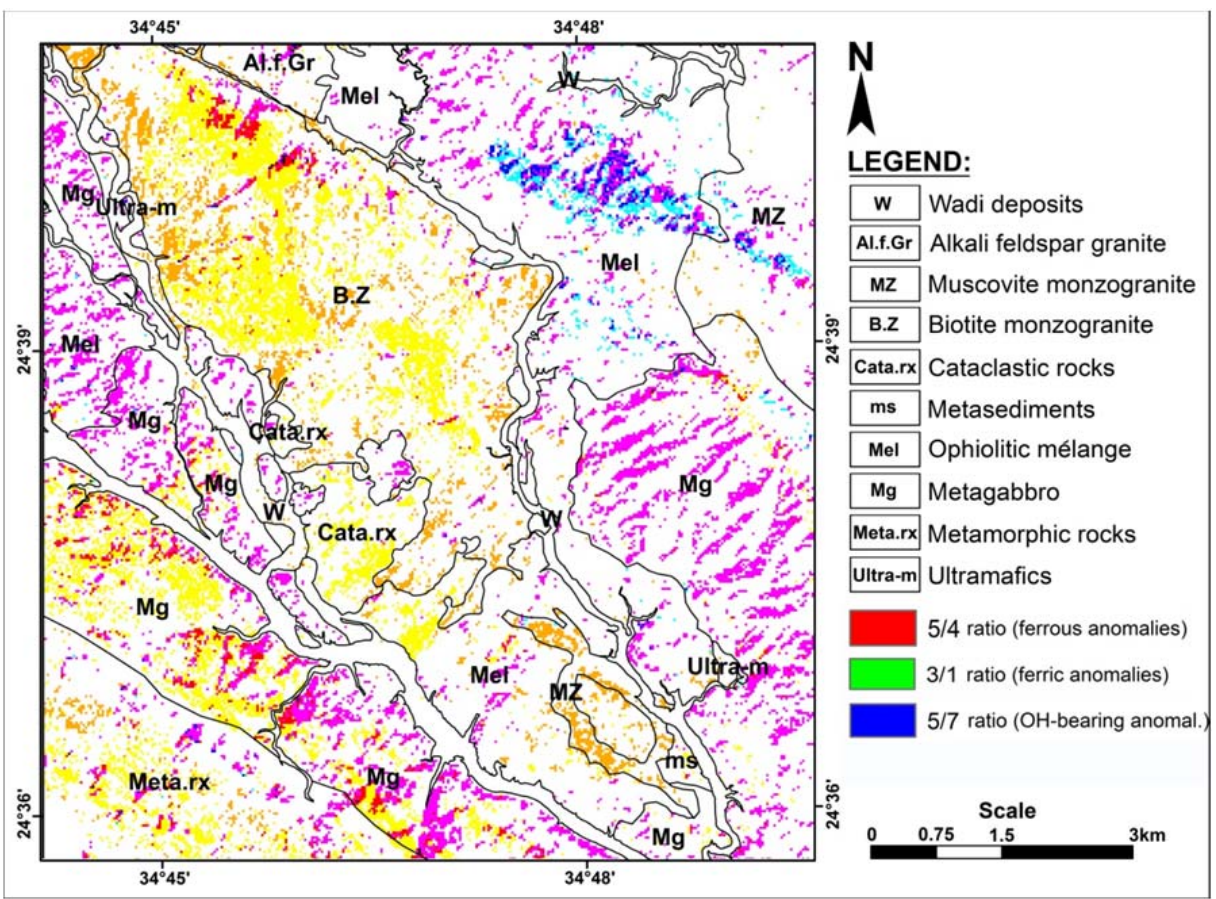

Fig. 7: Alteration zones in the study area of ferruginous (3/1 ratio), ferromagnesian (5/4 ratio) and $\mathrm{OH}-$ bearing minerals $(5 / 7$ ratio).
Fig. 8: Principal Component Analysis composite images (1,2 and 3) in RGB of the studied area.

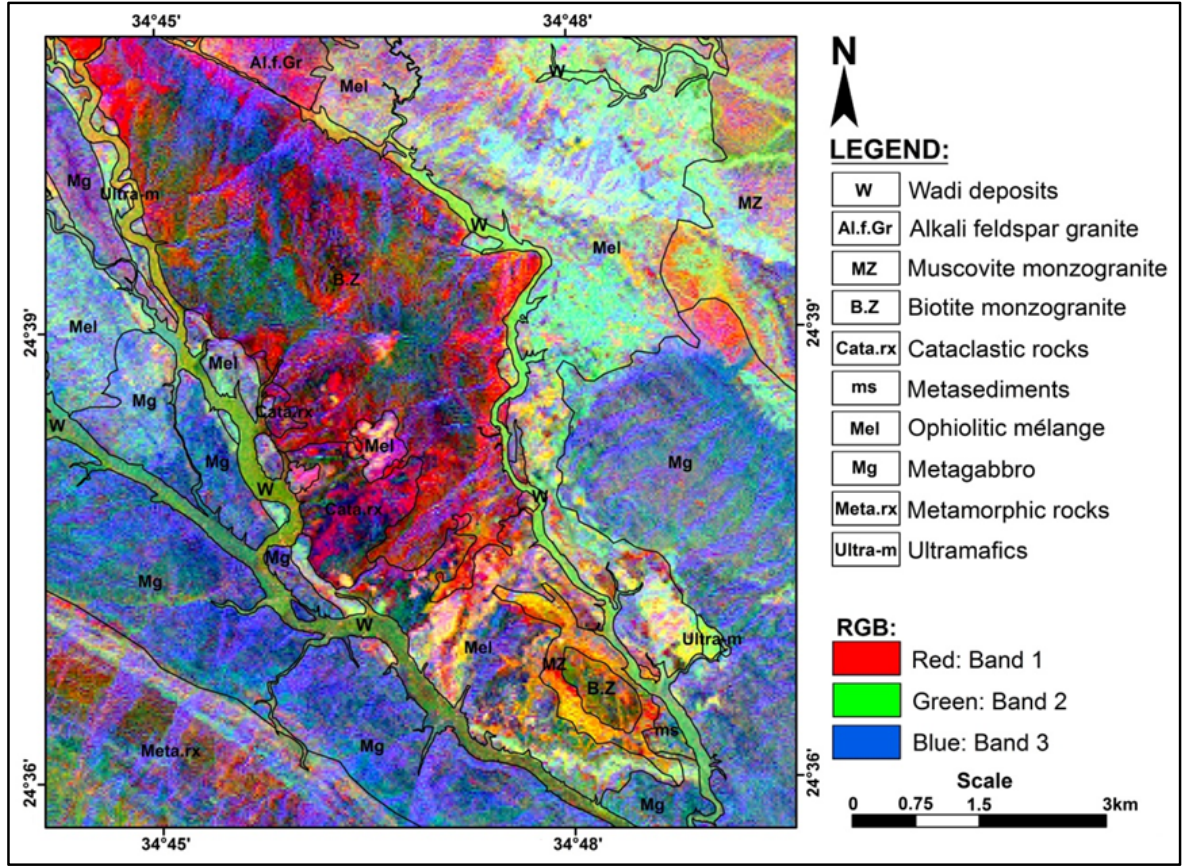


Integrated studies for mapping of uranium mineralization

\section{RESULTS AND DISCUSSION}

\section{Geologic Setting and Structural Lineaments of the Study Area}

Extraction of lineaments was carried out visually from Landsat 7 (ETM+) data using ARC map package. Different ETM+ bands were tested to select the optimal band for the lineament extraction. Visually extracted lineaments from Landsat $7\left(\mathrm{ETM}^{+}\right)$bands in study area show that the SWIR bands (5 and 7 bands) exhibit the highest lineament number compared to the visible (bands 1,2 and 3) and NIR (band 4). Figure (9) shows that the significant minor and major structural lineaments which have predominant NW-SE direction (as shown in the rose diagram of figure (9), while the major structure predominates mainly in the N-S while there are limited NE-SW direction. All extracted structural trends for the study area was interpreted from the digital Landsat 7 (ETM+) data during this research largely which coincide with the main trends of the previous geological mapping and previous literature for southern eastern desert. The recorded total number of fractures along the study area was 1949, meanwhile, number of dykes were 64 lines. These recorded numbers were close to those (1953 and 62, respectively) which obtained by Ibrahim (2009).

Lithological discrimination using Landsat 7 (ETM+) images, Conoco (1987) map and previous works (i.e. Sabet et al., 1976, El Ramly, et al., 1993, Saleh, 1997 and Ibrahim et al., 2002) revealed that the study area is mainly covered by ultramafic rocks, metamorphic rocks, metagabbros, ophiolitic mélange, metasediments, cataclastics, younger gabbros, biotite monzogranite, muscovite monzogranite, alkali feldspar granite, wadi deposits from oldest to youngest (Fig. 10).

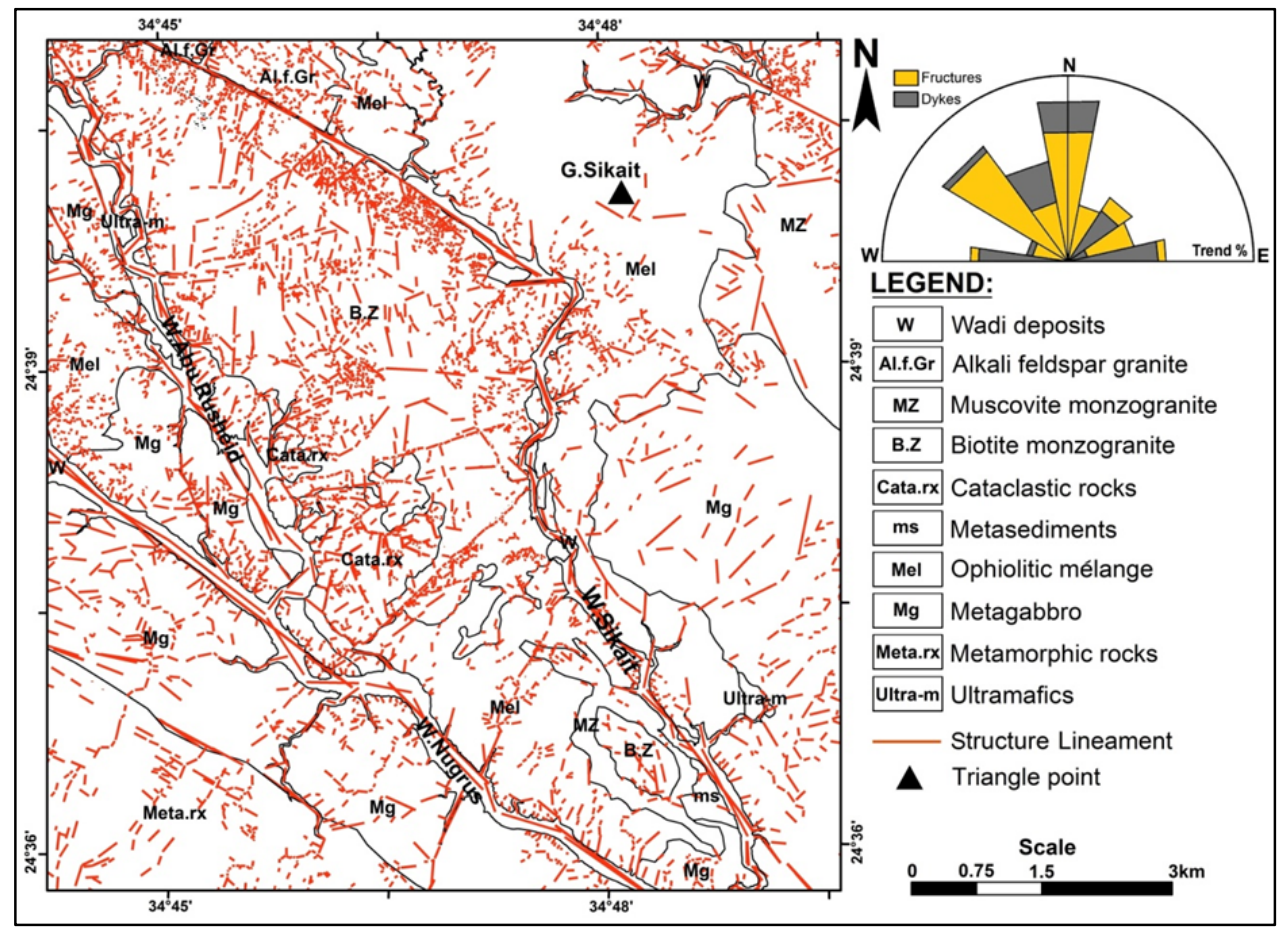

Fig. 9: Structure lineament patterns with rose diagram of Nugrus-SikaitAbu Rusheid area, South Eastern Desert, Egypt (Modified after Ibrahim, 2009).

\section{Radiometric Investigation}

\section{Geophysical spectrometric survey}

Spectrometric survey is measuring the concentration of equivalent uranium, equivalent thorium and potassium in the rocks of an area. The collected samples were processed and analyzed for ( $U$ in $\mathrm{ppm}$ ) and other associated elements like (Th in $\mathrm{ppm}$ ) and potassium (K\%). The relative concentrations of uranium with respect to potassium and thorium are important diagnostic factors in the recognition of possible uranium deposits (IAEA, 1988). Many authors have reported some anomalies associated and related to the rocks Nugrus-Sikait environs such as (Ibrahim et al., 2002, Rashed, 2005, Mansour, 2005 and Ibrahim et 
Mousa, M. I.

al., 2007). Analysis of radio-elements in the study area were presented potassium at three high potentiality zones which have NW-SE trend in the study area and ranges between (5.5-7.0\%), high potentiality zones was represented in cataclastic and monzogranite at Abu Rusheid and Sikait area (Fig. 11).

Fig. 10: Regional geologic map of Nugrus-Sikait-Abu Rusheid area, South Eastern Desert, Egypt (Modified after Saleh, 1997).
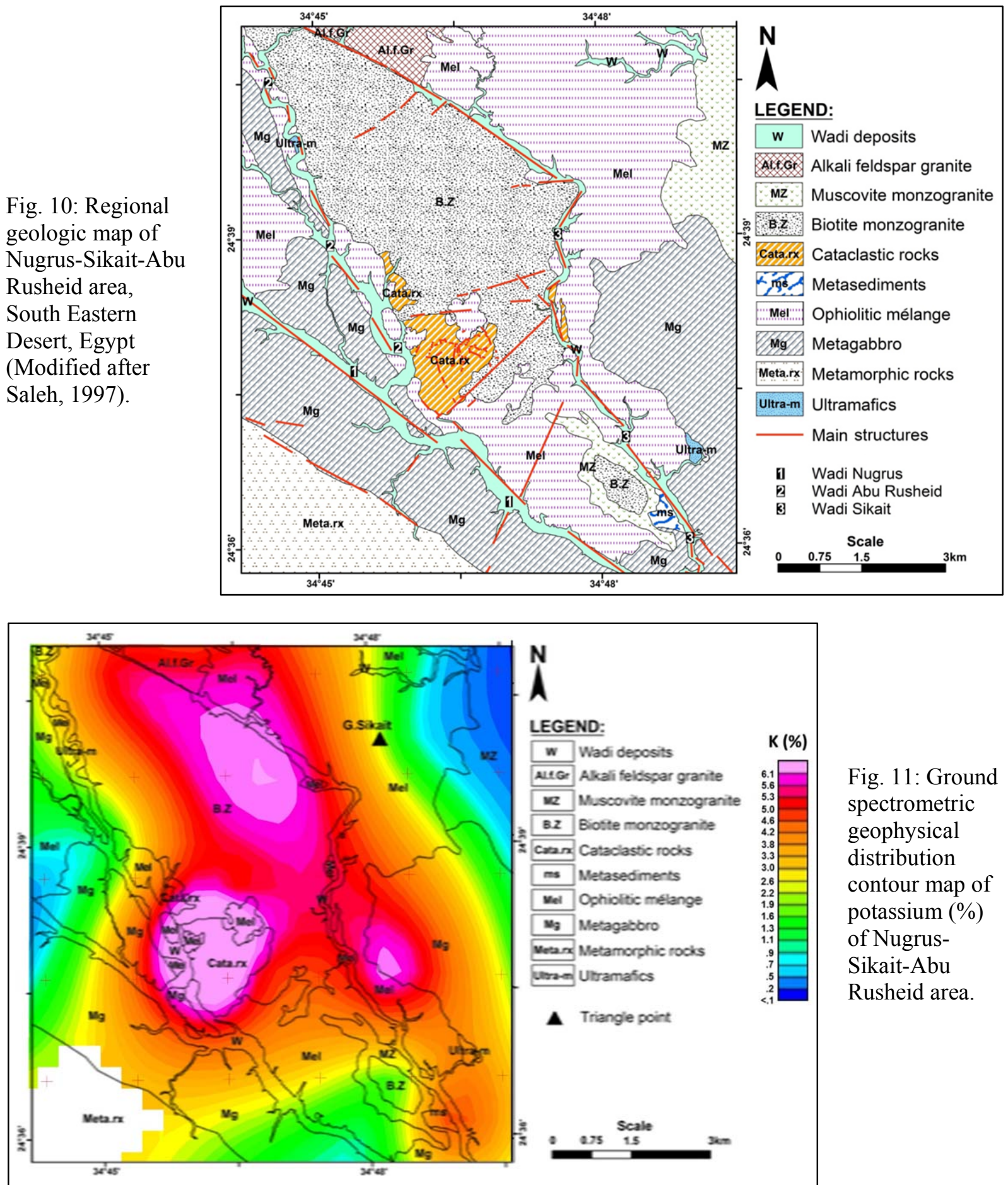

Fig. 11: Ground spectrometric geophysical distribution contour map of potassium (\%) of NugrusSikait-Abu Rusheid area.

Also uranium has two high potentiality zones in the study area which ranges between $(75-100 \mathrm{ppm})$ and represented in cataclastic rocks in the Abu Rusheid area which has NNE trend and at Nugrus in ophiolitic mélange (Fig. 12). 
Fig. 12: Ground spectrometric geophysical distribution contour map of equivalent uranium (ppm) of NugrusSikait-Abu Rusheid area.

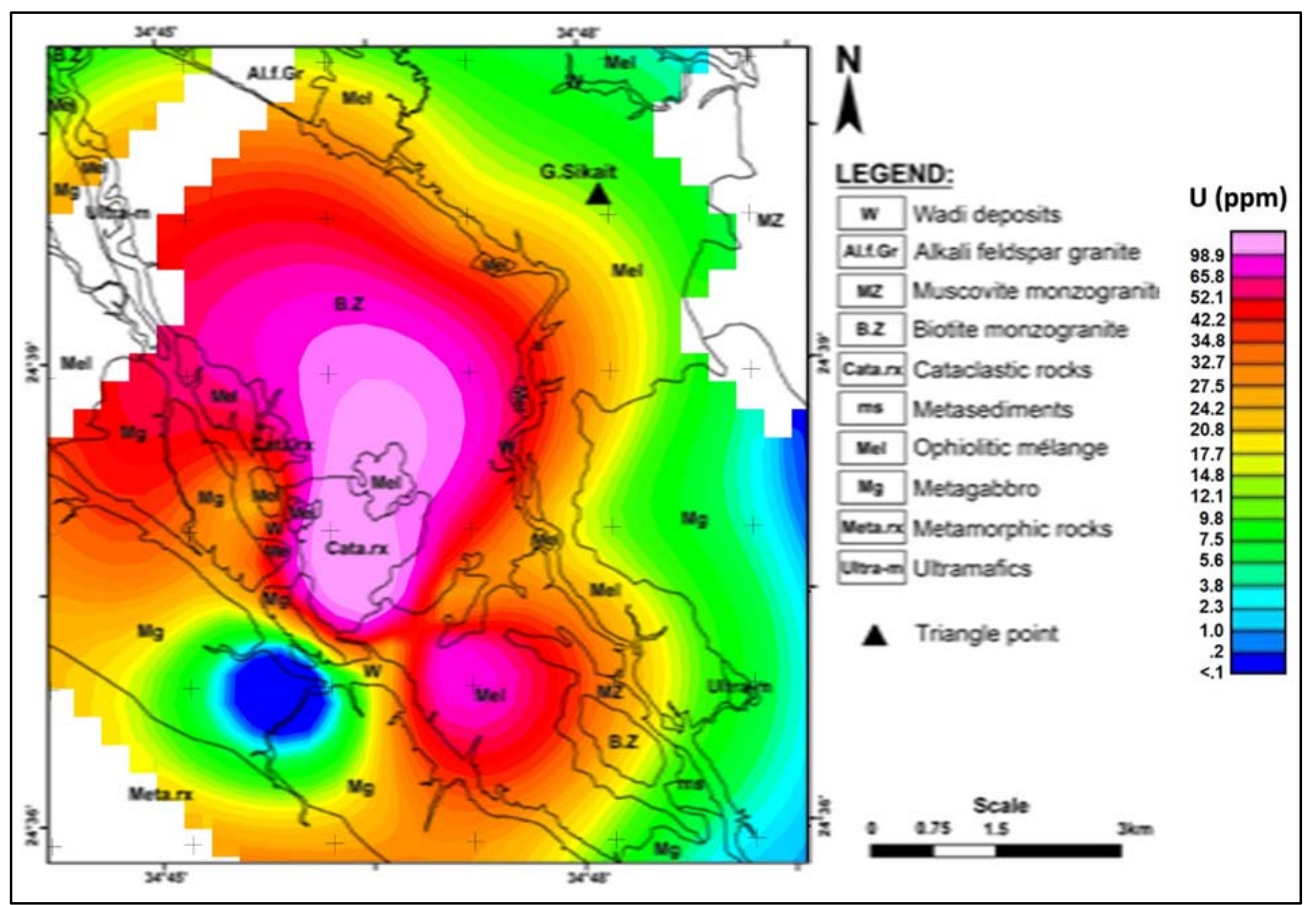

Thorium has one high potentiality zone in the study area which ranges between (300 - 400 ppm) and represented only in cataclastic rocks in the Abu Rusheid area and has nearly NW-SE trend (Fig. 13).

Ternary image for potassium in \%, thorium and uranium in ppm as in figure (14), represent the higher light appearance in white color, which refer of the the high radiometric zone at cataclastic rocks of the $\mathrm{Abu}$ Rusheid area. High radiometric zones represented by white color which refer to high reflection to all data, while the black refer to low reflection and high absorption for all mixed data. Pink color refers to equal amounts from uranium and potassium elements but yellowish color refer to mixture from red and green color vice mixture of uranium and thorium.

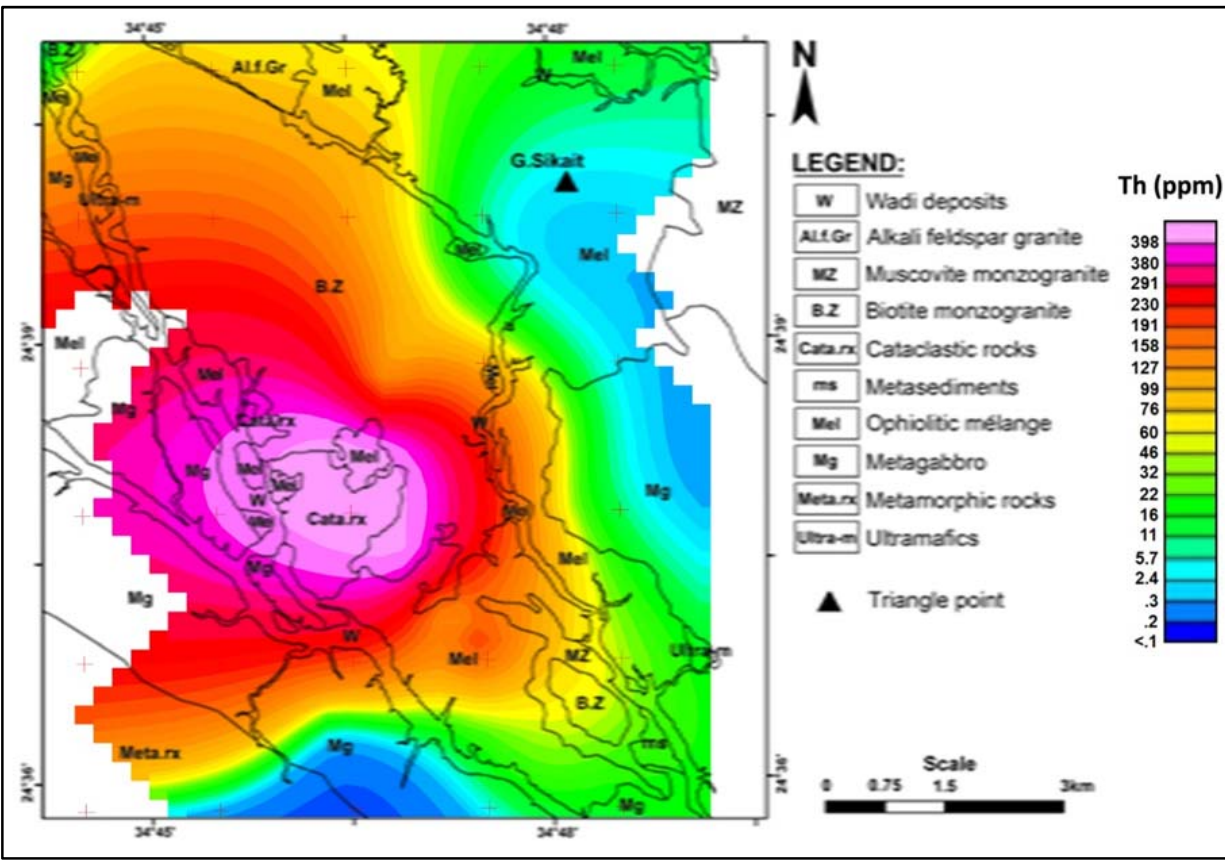

Fig. 13: Ground spectrometric geophysical distribution contour map for equivalent thorium (ppm) of Nugrus-Sikait-Abu Rusheid area. 
Mousa, M. I.

Fig. 14: Composite image for eU, eTh in (ppm) and $\mathrm{K}(\%)$ content of NugrusSikait-Abu Rusheid area.

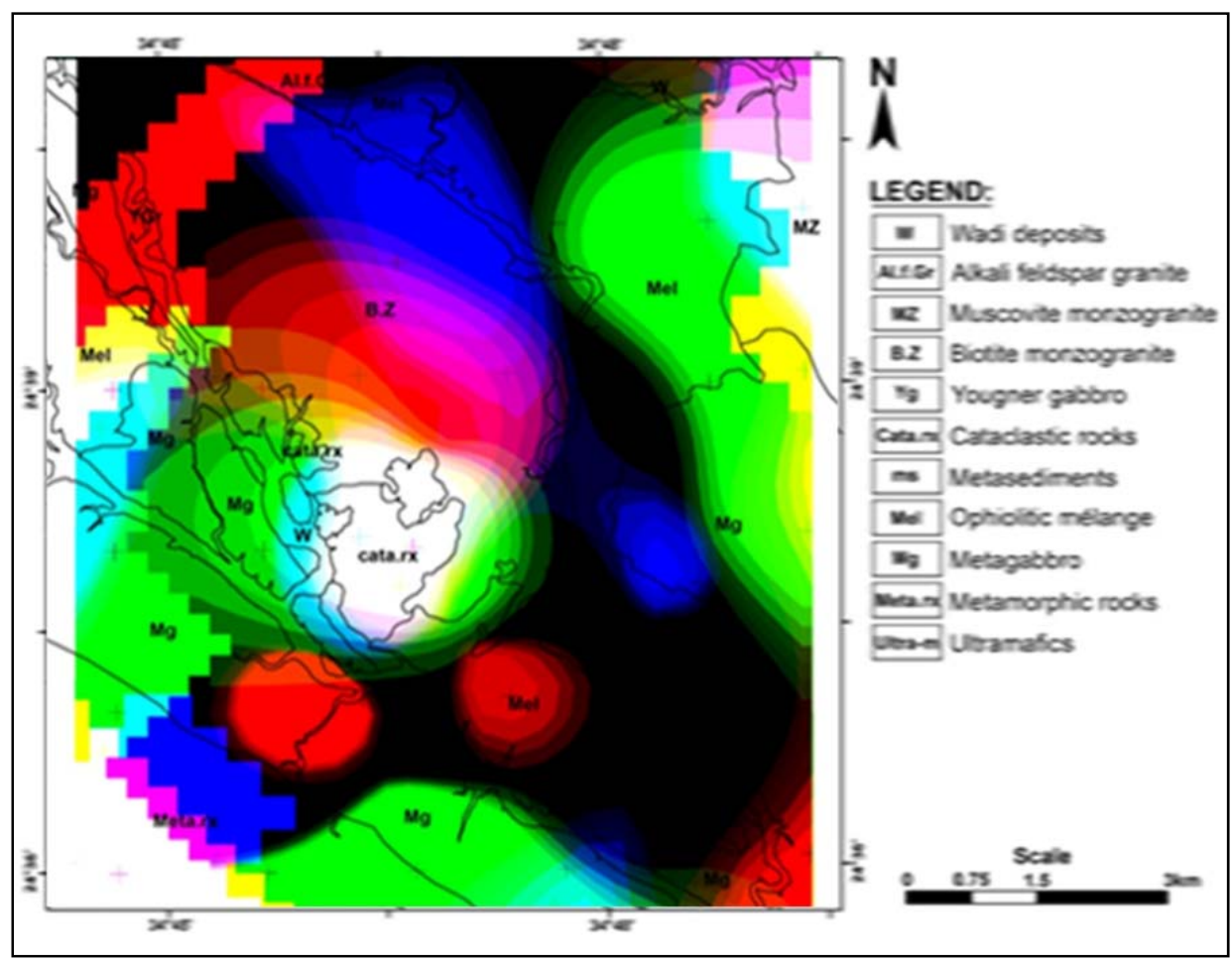

\section{Geochemical Studies}

Detailed Geochemical analysis for the Abu Rusheid area was plotted on the geological data and structural units to define geochemical anomalies of that area. Geochemical analysis for uranium (U in $\mathrm{ppm}$ ) and other associated elements like thorium (Th in ppm) and potassium (K in \%). Geochemical analysis of some elements (in ppm) such as rubidium, strontium, zinc, zirconium and other associated elements.

\section{Rubidium (Rb)}

Rubidium content ranges from 10 to $1300 \mathrm{ppm}$ and forms high concentrated occurrence in the Abu Rusheid area (Fig. 15), may confirm their usefulness as indicators or pathfinder elements for radioactive and nuclear metal deposits. This occurrence is associated with the ultra-mylonite, proto-mylonite and mylonite.

\section{Zinc (Zn):}

Zinc content ranges from 10 to 1600 ppm (Fig. 16) and concentrated in four high zones in the study area. This distribution may confirm their usefulness as indicators or pathfinder elements for radioactive and nuclear metal deposits. The first occurrence is associated with the ophiolitic mélange and covers an area of about $0.11 \mathrm{~km}^{2}$ with average content $\geq 1500 \mathrm{ppm}$. The second occurrence is associated with the mylonite and covers an area of about $0.5 \mathrm{~km}^{2}$ with average content $1400 \mathrm{ppm}$. The third occurrence is associated with the mylonite and protomylonite and covers an area of about $4.2 \mathrm{~km}^{2}$ with average content $1250 \mathrm{ppm}$. The last one is associated with the ultramylonite and silicified ultrammylonite and covers an area of about $3.76 \mathrm{~km}^{2}$ with average content $<1200 \mathrm{ppm}$.

\section{Zirconuim (Zr):}

Zirconium content ranges from 10 to $2600 \mathrm{ppm}$ and forms high concentrated occurrence in the area (Fig. 17), shows that $\mathrm{Zr}$ concentrations are markedly decreased in the north of the map due to the effect of dilution as the result of mixing with other barren materials. This occurrence is associated with the protomylonite, ultramylonite and mylonite and covers an area of about $2.61 \mathrm{~km}^{2}$ with average content 2000 ppm. 
Integrated studies for mapping of uranium mineralization

\section{Strontium (Sr)}

Strontium content ranges from 10 to $250 \mathrm{ppm}$ and forms high concentrated occurrence in the southern part of the area (Fig. 18). This occurrence is associated with the granitic rocks and covers an area of about $1.35 \mathrm{~km}^{2}$ with average content $170 \mathrm{ppm}$.

Fig. 15: Distribution map of rubidium (in ppm) of NugrusSikait-Abu Rusheid area.


Fig. 16: Distribution map of zinc (in ppm) of Nugrus-Sikait-Abu Rusheid area.

\section{Uranium (U)}

The uranium content ranges from 10 to $100 \mathrm{ppm}$ and forms three high concentrated occurrences in the Abu Rusheid area (Fig. 19). The first occurrence is associated with the granitic rocks and covers an area of about $0.17 \mathrm{~km}^{2}$ with average content $65 \mathrm{ppm}$. The second is associated with the mylonite and 
Mousa, M. I.

protomylonite and covers an area of about $15.8 \mathrm{~km}^{2}$ with average content $80 \mathrm{ppm}$. The third is associated with the mylonite and granitic rocks and covers an area of about $0.057 \mathrm{~km}^{2}$ with average content $40 \mathrm{ppm}$. Thorium (Th):

Fig. 17: Distribution map of zirconium (in ppm) of NugrusSikait-Abu Rusheid area.
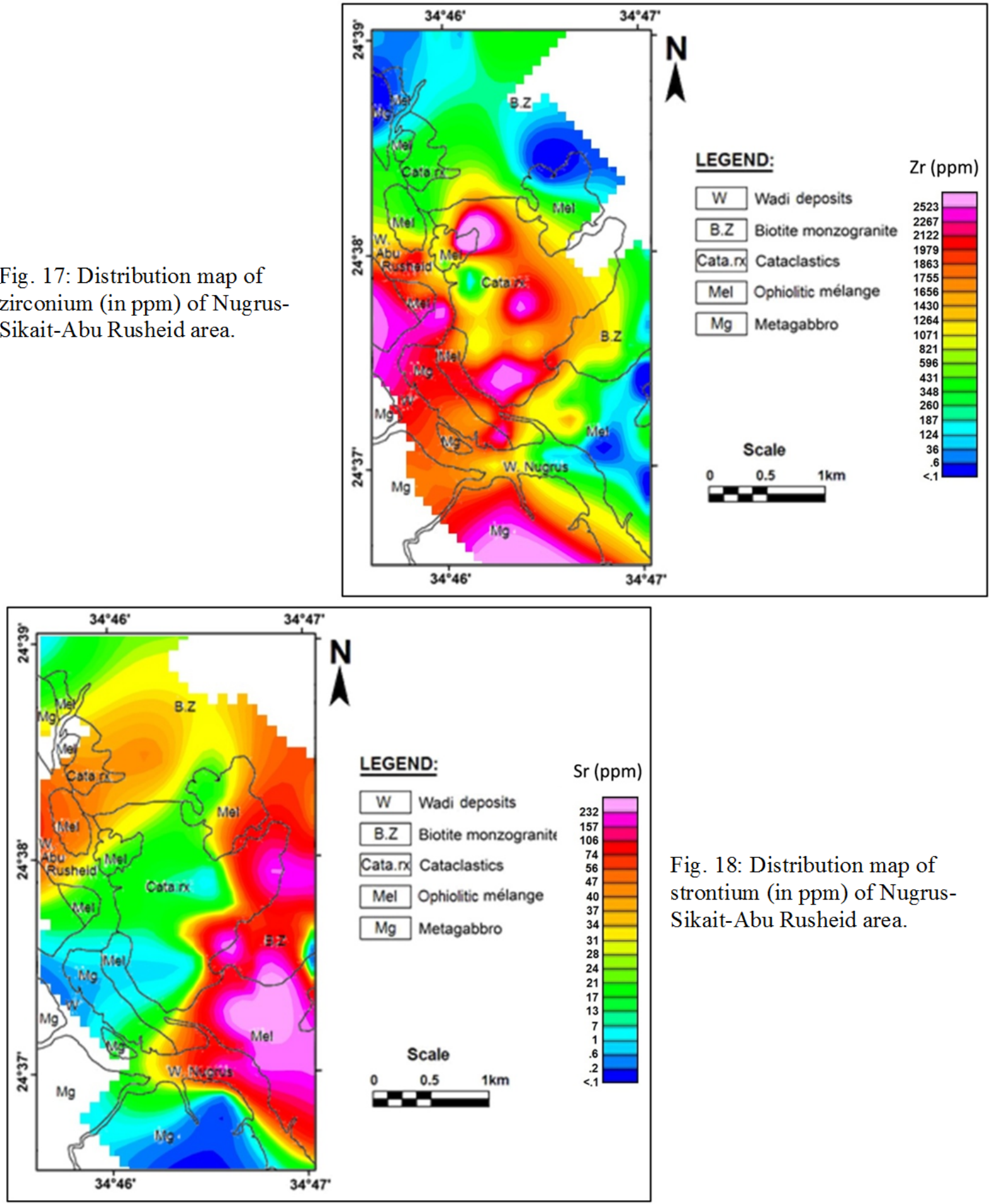

Fig. 18: Distribution map of strontium (in ppm) of NugrusSikait-Abu Rusheid area.

The thorium content over $400 \mathrm{ppm}$ was excluded. Thorium content ranges from 10 to $400 \mathrm{ppm}$ and form high concentrated occurrences in the Abu Rusheid area (Fig. 20). This occurrence is associated with the cataclastic rocks and covers an area of about $1.59 \mathrm{~km}^{2}$ with average content $275 \mathrm{ppm}$. 
Integrated studies for mapping of uranium mineralization

Fig. 19: Distribution map of uranium (in ppm) of NugrusSikait-Abu Rusheid area.
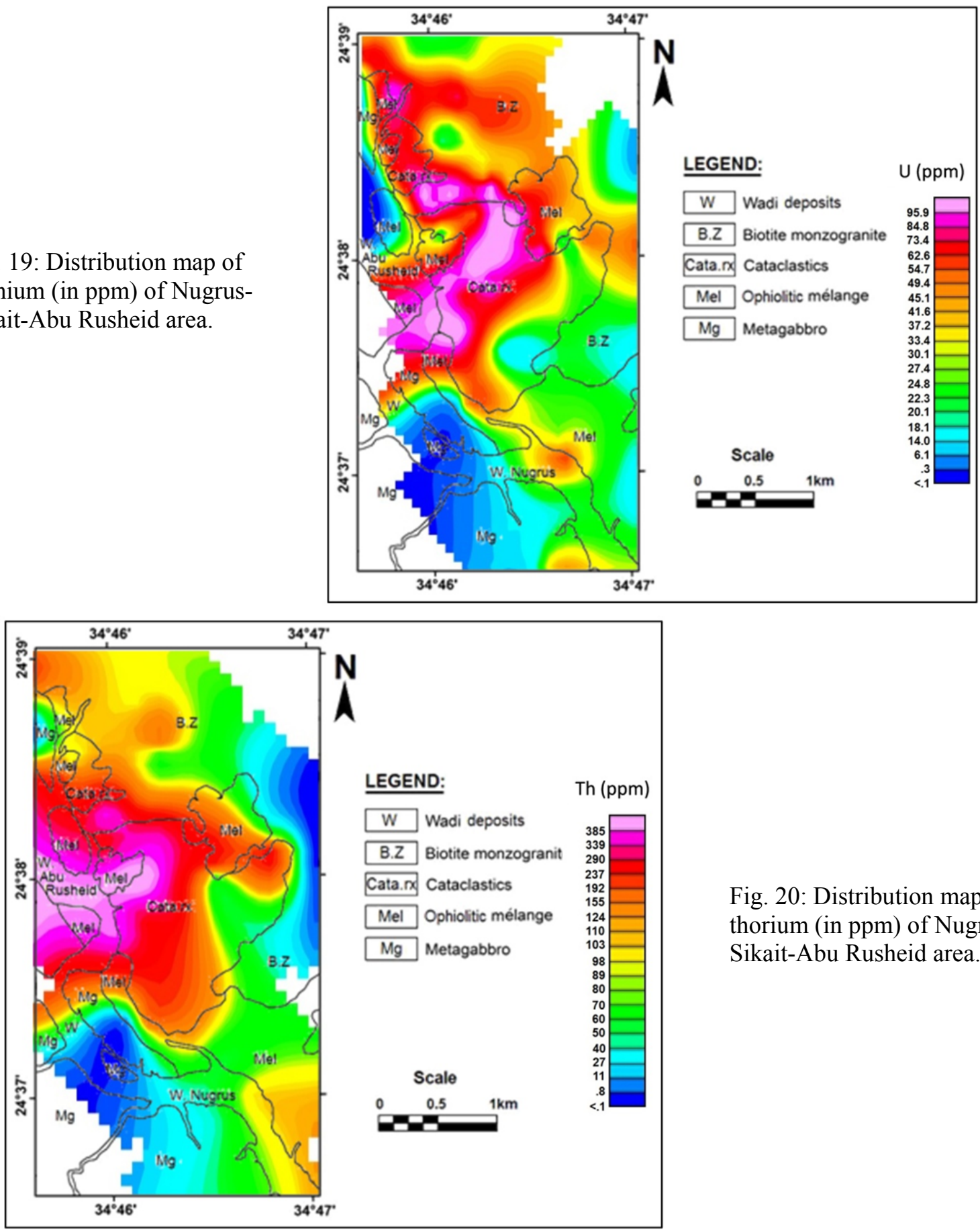

Fig. 20: Distribution map of thorium (in ppm) of NugrusSikait-Abu Rusheid area.

\section{Data Model for Multi-Disciplinary Analysis}

The study involved a multidisciplinary integrated approach for radio-elements exploration. Good multidisciplinary working depends on database for all data collected and good database model as in figure (21) for good output image by location and high attribute information about these result images. Such a multidisciplinary approach involving remote sensing, geochemical and geophysical technology assisted in deciphering zones of uranium mineralization.

Remote sensing, geological, geochemical and geophysical data were integrated in a stepwise manner to define the probable mineralized zones of uranium and associated minerals in the study area. The 
Mousa, M. I.

methodology involved satellite remote sensing based spectral studies supplemented by previous field geological investigations as well as geochemical sampling analysis and geophysical studies. Each technique supplemented the other, leading to increased confidence in interpretations at every stage. Each stage of study helped prioritization of target for subsequent stages of investigation.

Figure (21) mentioned to the model which are used for output result for multi-disciplinary data using ArcGIS software. Multidisciplinary analysis method has been used for spatial problems by coupling all data collected using geographic information systems (GIS).

The radio-element anomalies for $\mathrm{U}$ and $\mathrm{Th}$ (in ppm) and $\mathrm{K}(\%)$ of the Nugrus-Sikait area have been represented in figure (22) which falling within the cataclastic rocks.

Fig. 21: Data Model for exploratory analysis of radio-elements of Nugrus-Sikait-Abu Rusheid area.
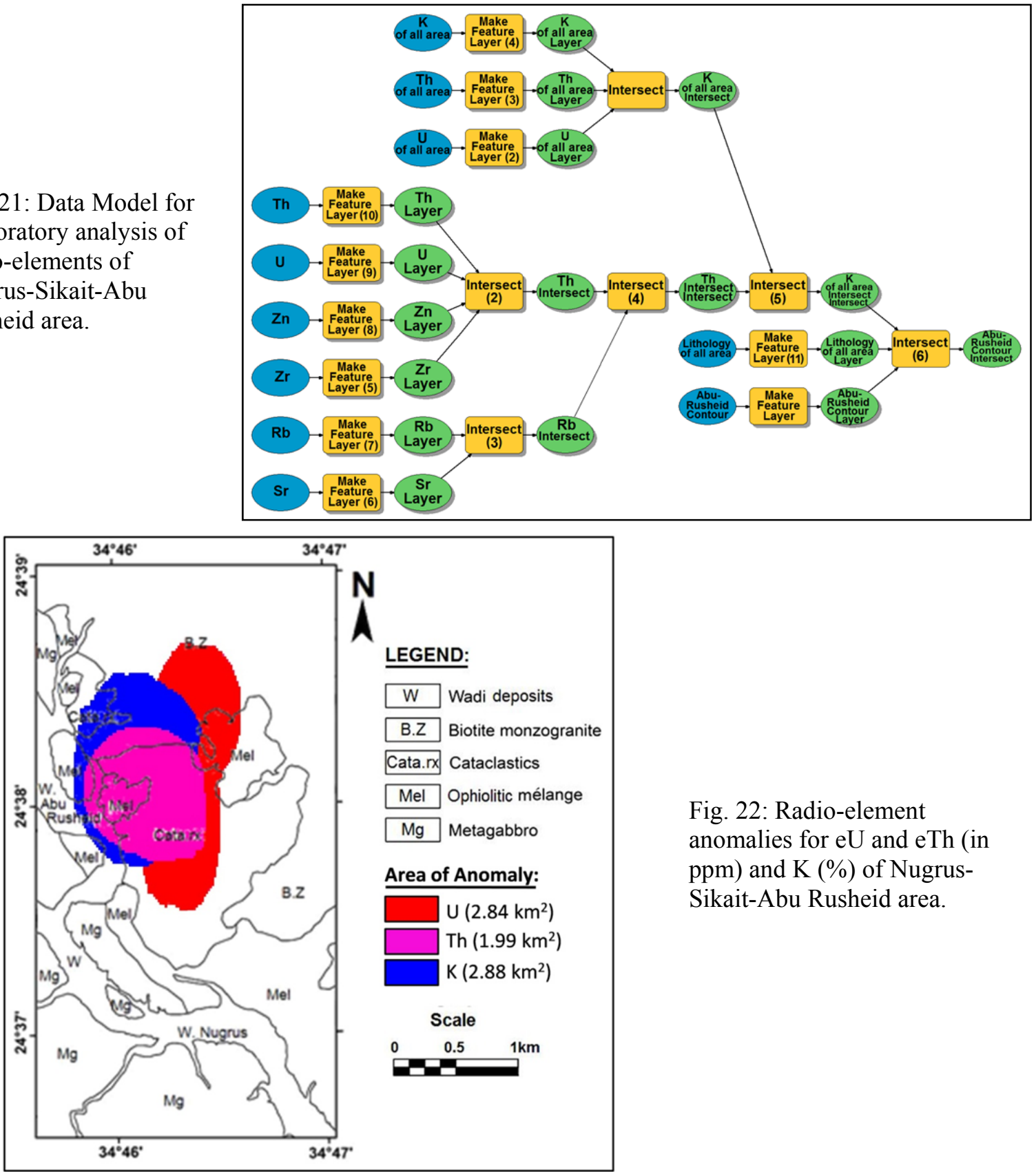

Fig. 22: Radio-element anomalies for eU and eTh (in ppm) and K (\%) of NugrusSikait-Abu Rusheid area. 


\section{Integrated studies for mapping of uranium mineralization}

On the other hand, figure (23) illustrates the geochemical anomalies for $\mathrm{Ur}$, $\mathrm{Th}$ and $\mathrm{Sr}$ at cataclastics and monzogranite in the study area. Figure (24) represents geochemical anomalies for $\mathrm{Rb}, \mathrm{Zn}$ and $\mathrm{Zr}$ at cataclastics in the study area. The result image for high radio-elements anomaly is shown in figure (25) for the study area.

Fig. 23: Geochemical anomalies for U, Th and Sr of Nugrus-Sikait-Abu Rusheid area.
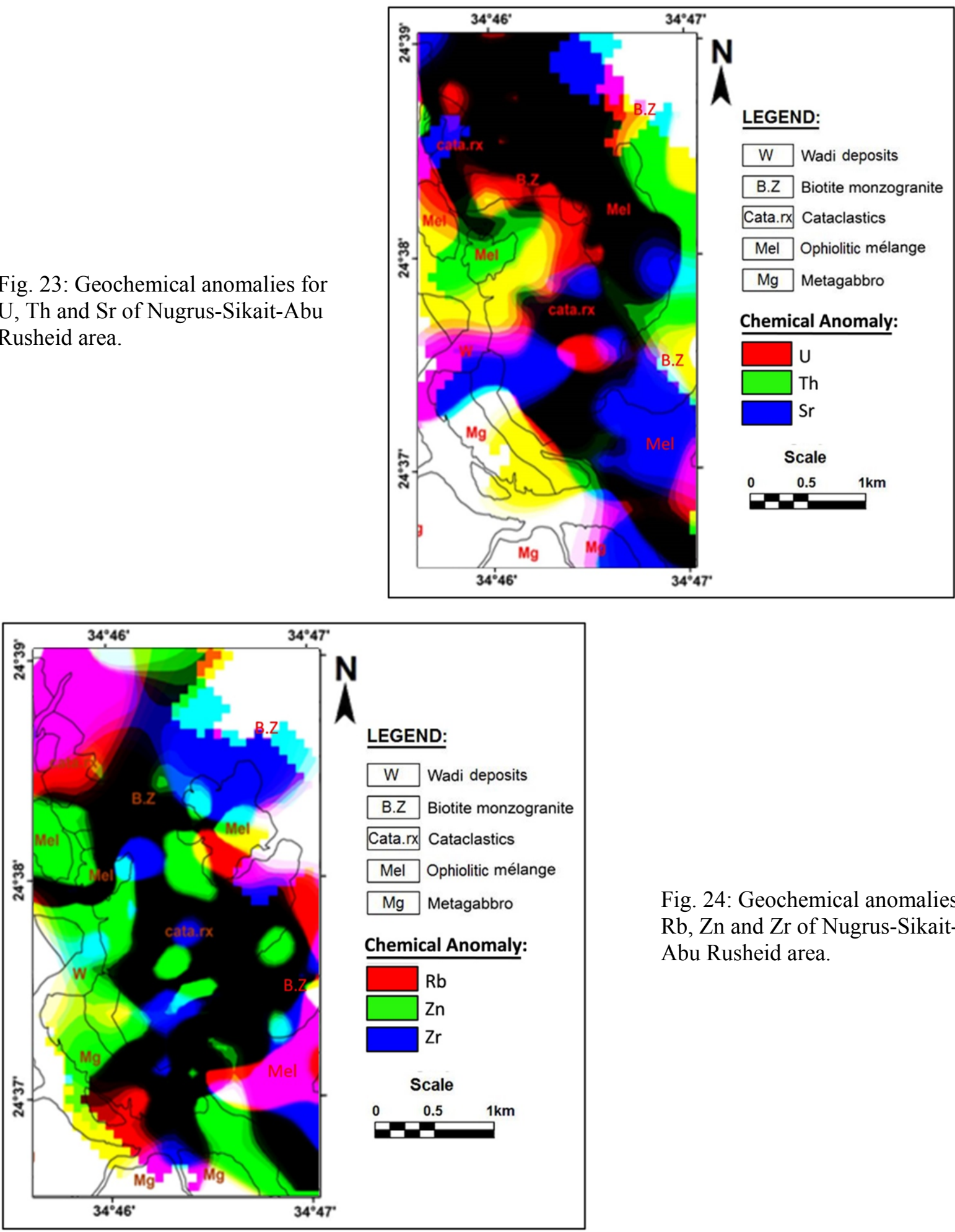

Fig. 24: Geochemical anomalies for $\mathrm{Rb}, \mathrm{Zn}$ and $\mathrm{Zr}$ of Nugrus-SikaitAbu Rusheid area. 
Mousa, M. I.

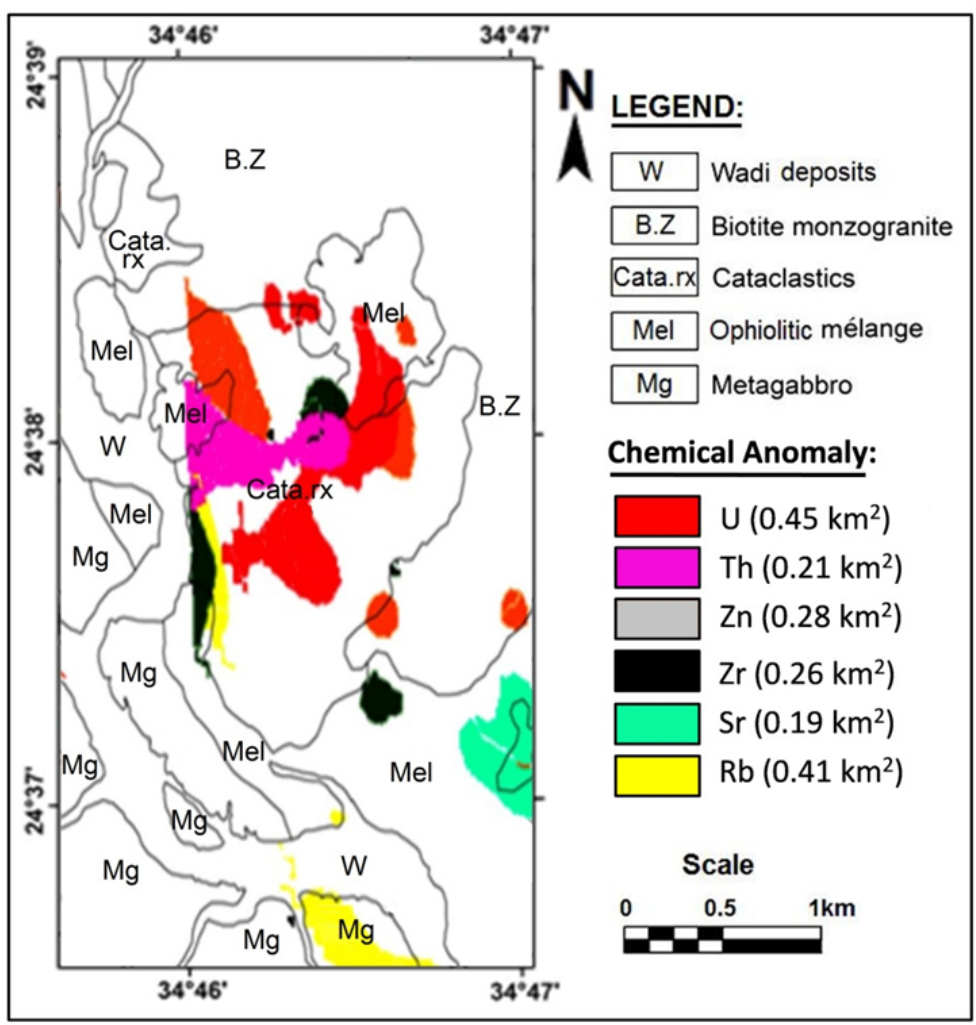

Fig. 25: Output anomaly map of Nugrus-Sikait-Abu Rusheid area in $\mathrm{km}^{2}$.

\section{SUMMARY AND CONCLUSION}

The final conclusions of the study were drawn based on integrated analysis and interpretation of all modes of investigation study. The multi-stage study and reduced exploration risk helped in making the best investment decisions on the project. Application of image processing technique was helpful in outlining and discriminating the lithologic units of the investigated area from interpretation of resulting images (FCC image, band ratios, PCA image. The result of the digital image processing of Landsat-7 satellite data leads to produce a false color composite image which has been constructed from combinations of the $\mathrm{ETM}^{+}$bands 7, 4 and 2 in red, green and blue respectively. Also, carried out composite image of $\mathrm{ETM}^{+}$band ratios $(5 / 7,5 / 4$ and 3/1 in red, green and blue, respectively) as well as principal component analysis. This new lithological discrimination in this study as well as structural lineament and topographic analysis construct the detailed geological map of the study area. Application of geophysical spectrometry technique was used for radio element interpretation for $\mathrm{K}$, Th and Ur to estimate highly anomaly locations. Application of geochemical analysis technique confirms the analytical results for chemical of the Abu Rusheid area, the presence of chemical elements such as rubidium and uranium, which it is responsible for high radioactive measurements in rocks in that region.

\section{REFERENCES}

Abdalla, H. M., Helba, H. A. and Mohamed, F. H. (1998): Chemistry of clumbite-tantalite minerals in rare metals granitoids, Eastern Desert, Egypt. Mineral. Mag., 62(6), 821-836.

Abu Elatta, S. A., Khaleal, F. M. and Rashed, M. A. (2013): Characteristics of madinat nugrus peraluminous leucogranite carrier of radioactive minerals, south Eastern Desert, Egypt. Res. Open J. Miner. Mini. Eng., 1(7), 15 - 34.

Ali, M. A. (2012): Mineral chemistry of monazite-(Nd), xenotime-(Y), apatite, fluorite and zircon hosting in lamprophyre dyke in Abu Rusheid area, South Eastern Desert, Egypt. Geologija, 55/1, 93-106.

Ali M. A., Lentz D. R. and Hall D. C. (2011): Mineralogy and geochemistry of Nb-, Ta-, Sn-, U-, Th-, and Zr-bearing granitic rocks from Abu Rusheid shear zones, South Eastern Desert, Egypt. Chin. J. Geochem., 30, 226-247. 
Integrated studies for mapping of uranium mineralization

Assran, S. M. A. and Mansour, G. M. R. (2005): Report on application of self-potential and horizontal loop electromagnetic techniques for Abu Rusheid area, South Eastern Desert, Egypt, Nuclear Materials Authority (NMA), (Unpublished Internal Report). 39 pp.

Bugrov, V. A., Abu El Gadeal, A. and Soliman, M. M., (1973): Rare-metallic albite as a new type of ore mineralization in Egypt. Ann. Geol. Surv. Egypt. III, p. 185-206.

Drury, S. A. (1993): Image Interpretation in Geology, $2^{\text {nd }}$ ed. Chapman and Hall, London.

Eid, A. S. (1986): Mineralogy and geochemistry of some mineralized rocks in W. El Gemal, Eastern Desert, Egypt. Unpublished Ph. D. Thesis, Ain Shams Univ. 165 pp.

El Ramly, M. F.; Greilling, R. O.; Kröner, A.; Rashwan, A. A. and Rasmy, H., (1993): Explanatory note to accompany the geological and structural maps of Wadi Hafafit area. Eastern Desert of Egypt. Geological Survey of Egypt. Paper No. 68. 53 p.

Egyptian Mineral Resources General Authority (EGSMA) (1989): Topographic map of G. Hafafit area scale $1: 50,000$.

Conoco Coral ltd. (1987): Geological map of Egypt, 1:500,000, NG36NE, Quseir. OTFH, Berlin.

Hassan, M. A. (1964). Geology and petrographical studies of the radioactive minerals and rocks in Wadi Sikait-Wadi El Gemal area. Eastern Desert, UAR, Unpublished M.Sc. Thesis. Fac. Scie., Cairo Univ., $165 \mathrm{pp}$.

Hassan, M. A., (1972): On the occurrence of columbite mineralization in Wadi Abu Rusheid Eastern Desert, Egypt Jour. Geol. 16(2): 283-291p.

Hassan, M. A. (1973). Geology and geochemistry of radioactive columbitebearing psammitic gneiss of Wadi Abu Rusheid. South Eastern Desert, Egypte. Annals of Geol. Surv. Egypt, V. III, p. 207-225.

Hassan, M. A. and El Shatoury, H.M. (1976). Beryl occurrences in Egypt. Mining Geology, 26, 253-262.

Higgins, M. W. (1975): Cataclastic rocks United States Government Printing office, Washington. 1-10 p.

IAEA (International Atomic Energy), (1988): Geochemical exploration for uranium. Technical Reports Series No. 284, Vienna, Austria, 96 pp.

Ibrahim, M. E., Assaf, H. S. and Saleh, G. M., (2000): Geochemical alteration and spectrometric analyses in Abu Rusheid altered uraniferous gneissose granites, South Eastern Desert, Egypt Chem. Erde. 60, 173-188.

Ibrahim, M. E., Saleh, G. M., Abd El Naby, H. H., Amer, T., Mahmoud, F. O., Abu El Hassan, A. A., Ibrahim, I. H., Aly, M. A., Azab, M. S., Rashed, M. A., Khalel, F. M. and Mahmoud, M. A. (2002): Uranium and associated rare metals potentialities of Abu Rusheid brecciated shear zone I, south Eastern Desert, Egypt, (Unpublished Internal Report), 107 pp.

Ibrahim, M. E., Saleh, G. M., Amer, T, Mahmoud, F. O., Abu El Hassan, A. A, Ibrahim, I. H., Aly, M. A., Azab, M. S., Rashed, M. A, Khaleal, F. M. and Mahmoud, M. A. (2004): Uranium and associated rare metals potentialities of Abu Rusheid brecciated shear zone II, South Eastern Desert, Egypt, (Unpublished Report), 141 pp.

Ibrahim M. E., El Tokhi M. M., Saleh G. M., Rashed M. A. (2006): Lamprophyre bearing REEs, South Eastern Desert, Egypt. $7^{\text {th }}$ Inter. Conf. Geochem., Fac. Sci. Alex. Univ., Alex., Egypt, 6-7 Sept., I:73$84 \mathrm{p}$.

Ibrahim, M. E., Abd El Wahed, A. A., Rashed, M. A., Khaleal, F. M., Mansour, G. M. R. and Watanabe, K. (2007): Comparative study between alkaline and calc-alkaline lamprophyres, Abu Rusheid area, south Eastern Desert, Egypt. The $10^{\text {th }}$ Inter. Min., Petrol., and Metall. Eng. Conf., Assuit Univ., 99-115 p.

Ibrahim, W. S. (2009). Structural setting and tectonic environment of Nugrus-Sikait area, South Eastern Desert, Egypt: implication on mineralization. Unpublished M.Sc. Thesis, Canal Suez Univ., 128 pp.

Ibrahim, T. M. M. (2011): Towards a geochemical and mineralogical classification of the rare metal granite in the Abu Rusheid area, Eastern Desert, Egypt. Al Azhar Bull. Sci., V. 22(1), 49-68 p.

Khaleal, F. M., Rashed, M. A. and Darwish, M. S. (2007): Base metals mineralization at Wadi Sikait, south Eastern Desert, Egypt. The $5^{\text {th }}$ Intern. Conf. Geol. Afr., V(1), 27-39 p.

Khaleal, F. M. (2005): Geologic evaluation of some rare metal resources in Nugrus-Siltait area, Eastern Desert, Egypt. Unpublished Ph.D. Thesis, Fac. Sci., Al Azhar Univ., 187 pp.

Krs, M., Soliman, A. A. H. and Amin, A. H. (1973): Geophysical phenomena over deep-seated tectonic zones in the southern port of the Eastern Desert of Egypt: Ann. Geol. Surv. Egypt. III, 125-138. 
Mahmoud, M. A. (2009): Highlight on the geology, geochemistry and spectrometry of the muscovite granites at Wadi El Gemal area, South Eastern Desert, Egypt. Unpublished Ph. D. Thesis, Fac. Sci., Suez Canal Univ., 233 pp.

Mansour, G. M. R. (2005): Geological and geophysical investigations of mineralized structures in Wadi Abalea and its surroundings, Abu Rusheid area, south Eastern Desert, Egypt. Unpublished Ph.D. Thesis, Fac. Sci., Mans. Univ. (Demiatta), 155 pp.

Omar, S. A., (2001): Characterization and evaluation of some beryl occurrencec in the Eastern Desert, Egypt. Ph. D. Thesis, Cairo univ. Egypt, 258 pp.

Oraby, F., Abu Elhassan, E. A., Omar, S., Khaleal, F. M. and Mohamed, M. A., (2003): Delimitation and evaluation of Beryllium resources in the Eastern Desert, Egypt. (Unpublished Internal Report).

Osman, R. A. (2007): Potentiality of rare metals minerals in the uraniferous gneisses, Wadi Abu Rusheid, south Eastern Desert, Egypt. Ph. D. Thesis, Fac. Sci., Ain Shams Univ., 120 pp.

Rashed, M.A. (2005): Geologic studies on a new occurrence of nuclear materials in Abu Rusheid area, south Eastern Desert, Egypt. Unpublished Ph. D. Thesis, Fac. Sci., Mans. Univ. (Demiatta), 139 pp.

Raslan, M.F. (2008): Occurrence of Ishikawaite (Uranium-rich Samarskite) in the mineralized Abu Rusheid gneiss, south Eastern Desert, Egypt. Int. Geol. Rev., 50, 1132-1140 p.

Sabet, A. H., Tsogoev, V. B., Bordonosov, V. P., Shablovsky, R. G., and Kossa, M. (1976): On the geologic structures, laws of localization and prospects of Abu Rusheid rare metal deposit. Ann. Geol. Surv. Egypt. VI, 130-139.

Sabins, F. F. (1999): Remote sensing for mineral exploration. Ore Geology Reviews, 14, 157-183 p.

Saleh, G. M. (1997): The potentiality of uranium occurrences in W. Nugrus Area, South Eastern Desert, Egypt. Unpublished Ph. D. Thesis, Mans. Univ. Egypt, 171 pp.

Sultan, M., Arvidson, R. E. and Sturchio, N. (1987): Lithologic mapping in arid regions with Landsat thematic mapper data: Meatiq dome, Egypt. Geol. Soc. Amer. Bull., 99, 748-762 p. 
Integrated studies for mapping of uranium mineralization

دراسات متكاملة لرسم خرائط تمعدنات اليورانيوم في منطقة "تجرس-سكيت-أبو رشيد" جنوب شرق الصحراء، مصر. مدحت إسماعيل أحمد ، جهاد محمد رضا ، عاطف حسن عبد العظيم وخالد الحسينى محمد

هيئة المواد النووية، القاهرة ، مصر

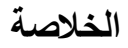

تتتاول الدراسة إستخدام العديد من البيانات لمنطقة "نجرس-سيكيت-أبو رشيد" بجنوب الصحراء الشرقية، مصر ، وتضمنت

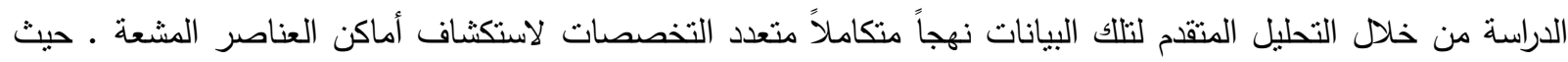
أدت هذه الطريقة إلى تحسن كبير في تقسير البيانات السطحية بإستخدام الخوارزميات لمعالجة المسوحات الجيوفيزيائية والتحاليل الجيوكيميائية للصخور المختلفة في منطقة الدراسة التى تم من خلالها التعرف على المواقع ذات الإشعاعية العالية .

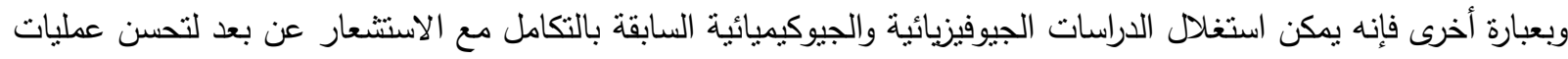

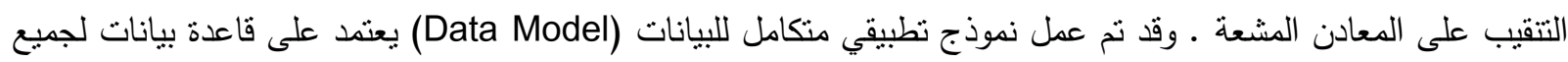

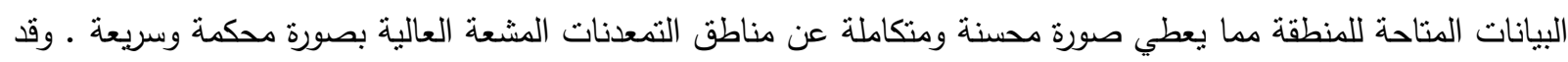
تم إجراء التمبيز الصخري من خلال المرئيات الفضائية من نوع لاندسات-V باستخدام حزم برمجيات إرداس إيماجين، أرك جى

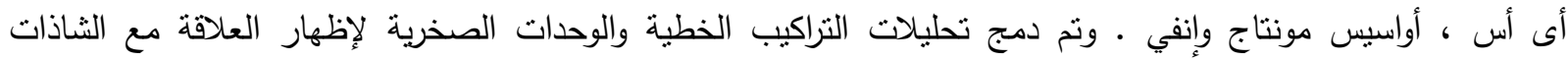
الإثعاعية فى منطقة الدراسة .

وقد تحقق الهدف الأساسى للاراسة في شكل خريطة للشاذات الإشعاعية ممثلة مكانياً وكمياً من خلال تكامل البيانات

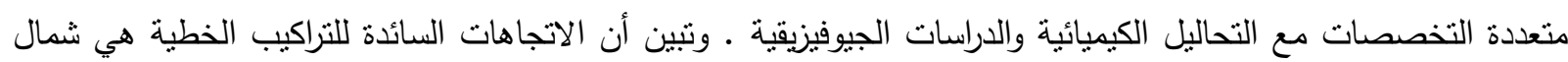

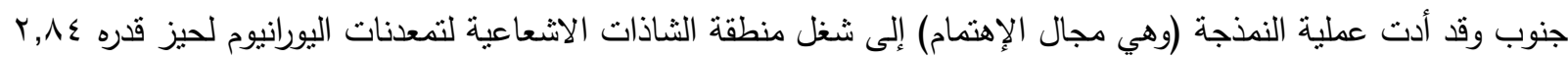

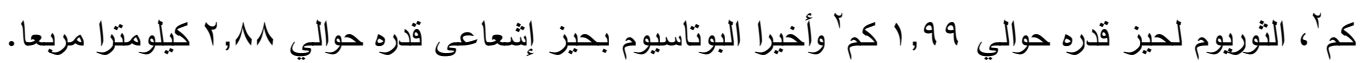
وأدى الإهتمام بالتحليل الجيوكيمبائي لعنصري الروبيديوم واليورانيوم أنها كانت الأعلى محنوى في الصخور التهشمية لهنطقة

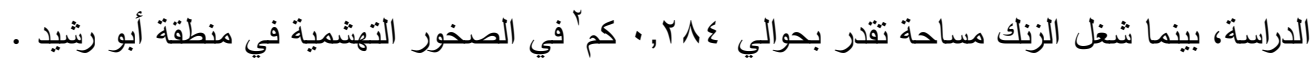

